\title{
Analisis Kinerja Keuangan Pada PT Asuransi Ramayana Tbk Dengan Pendekatan Cash Flow Untuk Tahun 2014-2017
}

\author{
Julia T. Wahani \\ Tinneke M. Tumbel \\ Dantje Keles \\ Jurusan Ilmu Administrasi Program Studi Administrasi Bisnis \\ Fakultas Ilmu Sosial dan Politik Universitas Sam Ratulangi Manado \\ Email: trivenawahani13@gmail.com
}

\begin{abstract}
This study aims to determine the financial performance of PT Asuransi Ramayana Tbk by using a cash flow ratio analysis. The type of data used in this study is quantitative data. The data source used in this study is secondary data sources. The technique of collecting data using the documentation method is by retrieving data contained in the Indonesia Stock Exchange. The data analysis tool used is the Operating Cash Flow Ratio (AKO), Operating Cash Flow Ratio to Total Debt (AKOTH), Cash Flow Ratio to Capital Expenditures (AKOPM) and Cash Flow Ratio to Net Income (AKOLB). The results of this study indicate that the financial performance of PT Asuransi Ramayana Tbk. based on the 2014-2017 operating cash flow ratio is not good because it is below the value 1. So that insurance companies are unable to pay current and total debt obligations through operating cash flows, difficulty financing their capital expenditure through operating cash flows, and the possibility that the company has not been able to pay dividends to customers using operating cash flows. PT Asuransi Ramayana Tbk must increase company revenue and reduce excessive investment expenditure.
\end{abstract}

Keywords: Financial performance; Cash flow ratio.

\section{Pendahuluan}

Perkembangan industri asuransi di Indonesia yang begitu cepat dan semakin baik setiap harinya. Dimana semakin hari semakin banyak nasabah yang menggunakan layanan asuransi dalam kehidupannya. Oleh karena itu, selain meningkatkan pelayanan kepada nasabah untuk memperluas dan memajukan bisnis yang mereka jalankan perusahaan asuransi dituntut harus mempunyai keunggulan kompetitif agar mampu meningkatkan kinerja yang dimilikinya. Menurut Fahmi
(2014), Kinerja keuangan adalah suatu analisis yang dilakukan untuk melihat sejauh mana perusahaan telah melaksanakan dengan menggunakan aturan-aturan pelaksanaan keuangan secara baik dan benar. Kinerja keuangan suatu perusahaan dapat dilihat pada laporan keuangan yang dimiliki oleh perusahaan. Laporan keuangan adalah salah satu faktor utama dalam menilai kinerja perusahaan, baik atau tidaknya keuangan perusahaan menjadi indikasi penilaian terhadap perusahaan tersebut. Salah satu bentuk 
laporan keuangan yang biasa digunakan perusahaan adalah laporan arus kas. Dalam laporan ini akan terlihat arus kas masuk dan arus kas keluar dari kegiatan usaha yang digunakan sebagai salah satu analisis keuangan yang sangat bermanfaat bagi manajemen perusahaan. Laporan arus kas sangat penting bagi perusahaan asuransi sebagai alat pertanggungjawaban arus kas masuk dan arus kas keluar selama periode pelaporan, membantu manajemen dalam meminimalkan risiko yang akan terjadi, serta mengetahui keadaan kas untuk menjaga likuiditas. Laporan arus kas bermanfaat untuk mengevaluasi perubahan aktiva bersih, struktur keuangan, sebagai indikator jumlah arus kas di masa yang akan datang, untuk menilai kecermatan atas taksiran arus kas yang telah dibuat sebelumnya, serta untuk menilai kemampuan perusahaan asuransi dalam menghasilkan kas dan setara kas. Laporan arus kas dapat memprediksi kemajuan perusahaan asuransi di setiap tahun berjalan agar tidak mengalami kerugian, kebangkrutan dan mampu bertahan dalam krisis ekonomi. Salah satu perusahaan yang ada di Indonesia dan masih bertumbuh adalah PT Asuransi Ramayana Tbk. Perusahaan ini awalnya diberikan nama PT Maskapai Asuransi Ramayana. Tujuan didirikan perusahaan asuransi untuk memenuhi kebutuhan proteksi barang atas barang impor dan ekspor. PT Asuransi Ramayana termasuk pada asuransi umum, yang memberikan perlindungan terhadap kerugian ekonomi yang terjadi karena kerusakan atau kehilangan aset. PT Asuransi Ramayana Tbk ini mendapatkan penghargaan-penghargaan, dari info bank dan warta ekonomi.

Berdasarkan latar belakang yang telah diuraikan sebelumnya, maka perumusan masalah dalam penelitian ini adalah bagaimana kinerja keuangan PT Asuransi Ramayana Tbk selama periode tahun 2014-2017 berdasarkan tolak ukur rasio arus kas. Dengan rumusan masalah tersebut dapat diketahui bahwa kinerja keuangan PT Asuransi Ramayana Tbk belum mampu memenuhi standar rasio arus kas.

\section{Asuransi}

Asuransi yang dikenal di Indonesia antara lain asuransi jiwa, asuransi kerugian dan asuransi kesehatan. Asuransi kerugian adalah asuransi yang melindungi harta benda, misalnya rumah beserta isinya, apartemen, mobil dan lain-lain. Dan asuransi kesehatan adalah asuransi yang menanggung risiko yang menyangkut dengan nyawa, misalnya seseorang menderita penyakit dan harus berobat di rumah sakit. (Danarti 2011:15) Pada prinsipnya pihak perusahaan asuransi mem- 
perhatikan masa depan kehidupan dan turut memikirkan serta berusaha untuk memperkecil kerugian yang mungkin timbul akibat terjadi risiko dalam me-laksanakan kegiatan usaha, baik ter-hadap perusahaan atau pribadi.

\section{Kinerja Keuangan}

Kinerja keuangan adalah hasil atau prestasi yang telah dicapai oleh manajemen perusahaan dalam mengelola aset perusahaan secara efektif selama periode tertentu. (Rudianto 2013:189) Kinerja keuangan sangat dibutuhkan oleh perusahaan untuk mengetahui dan mengevaluasi tingkat keberhasilan perusahaan berdasarkan aktivitas keuangan yang telah dilaksanakan. Kinerja keuangan merupakan suatu hasil atas prestasi yang telah dicapai oleh perusahaan dalam menjalankan fungsinya dan pengelolaan dana perusahaan secara efektif dan efisien selama periode tertentu. Pengukuran kinerja sangat diperlukan oleh perusahaan untuk mengetahui dan mengevaluasi sampai dimana tingkat keberhasilan perusahaan berdasarkan aktivitas yang telah dijalankan sebelumnya. Pengukuran kinerja dapat dilakukan dengan berbagai macam ukuran dan biasanya berdasarkan data laporan keuangan perusahaan. Pengukuran kinerja dilakukan dengan menganalisis laporan keuangan dengan menggunakan rasio-rasio keuangan perusahaan. Rasio menggambarkan suatu hubungan yang dapat memberikan penjelasan atau gambaran kepada menganalisa tentang baik dan buruknya keadaan posisi keuangan perusahaan.

\section{Laporan Keuangan}

Dibuatnya laporan keuangan oleh suatu perusahaan tentunya memiliki tujuan dan manfaat. Menurut Fahmi (2012:5) tujuan laporan keuangan adalah untuk memberikan informasi kepada pihak yang membutuhkan tentang kondisi suatu perusahaan dari sudut angka.

Secara lebih rinci, Kasmir (2014:10) mengungkapkan bahwa laporan keuangan bertujuan untuk: Memberikan informasi tentang jenis dan jumlah aktiva (aset) yang dimiliki perusahaan pada saat ini, memberikan informasi tentang jenis dan jumlah kewajiban dan modal yang dimiliki perusahaan saat ini, memberikan informasi tentang jenis dan jumlah pendapatan yang diperoleh pada suatu periode tertentu, memberikan informasi tentang jumlah biaya dan jenis biaya yang dikeluarkan, memberikan informasi tentang perubahanperubahan yang terjadi terhadap aktiva, pasif dan modal perusahan dan memberikan informasi tentang kinerja manajemen perusahan dalam suatu periode. 


\section{Laporan Arus Kas}

Laporan arus kas sebagai salah satu komponen laporan keuangan wajib dibuat oleh perusahaan harus menyajikan transaksi arus kas masuk dan transaksi arus kas keluar selama periode tertentu, dan mengklarifikasikan menurut aktivitas operasi investasi dan pendanaan. Menurut Ikatan Akutansi Indonesia definisi arus kas adalah "Arus kas adalah arus kas masuk dan arus kas keluar atau setara kas". Arus kas masuk merupakan jumlah kas yang mengalir masuk dan keluar dari suatu perusahaan dalam suatu periode tertentu. Arus Kas Masuk (Cash Inflow) merupakan aliran sumber -sumber darimana kas diperoleh, misalnya penerimaan dari penjualan secara tunai, penerimaan piutang yang telah dijadwalkan, penerimaan modal saham dan lain-lain. Arus Kas Keluar (Cash Outflow) merupakan kebutuhan kas untuk pembayaran-pembayaran, misalnya membayar upah dan gaji, pembelian aktiva tetap, pembayaran dividen dan lain-lain.

\section{Rasio Cash Flow}

Salah satu analisis kinerja keuangan dengan menggunakan informasi laporan arus kas adalah rasio arus kas. Analisis arus kas ini menggunakan komponen dalam arus kas dan komponen neraca dan laba rugi sebagai informasi dalam analisis rasio. Menurut Darsono dan Ashari (2005:91) dalam Oktaviana (2017) alat analisis rasio arus kas yang diperlukan untuk menilai kinerja keuangan perusahaan antara lain:

1. Rasio Arus Kas Operasi (AKO)

Rasio arus kas operasi menghitung kemampuan arus kas operasi dalam membayar kewajiban lancar. Rasio ini diperoleh dengan membagi arus kas operasi dengan kewajiban lancar. Dalam hal ini, Rasio arus kas operasi berada dibawah 1 yang berarti terdapat kemungkinan perusahaan tidak mampu membayar kewajiban lancar, tanpa menggunakan arus kas dari aktivitas lain.

2. Rasio Arus Kas Operasi terhadap Total Hutang

Rasio arus kas operasi terhadap total hutang menunjukkan kemampuan arus kas operasi perusahaan dalam melunasi seluruh kewajibannya, baik kewajiban lancar maupun kewajiban jangka panjang. Rasio yang rendah menunjukkan bahwa perusahaan memiliki kemampuan yang kurang baik dalam membayar semua kewajibannya dengan menggunakan arus kas yang berasal dari aktivitas normal operasi perusahaan.

3. Rasio Arus Kas Operasi terhadap Pengeluaran Modal

Rasio ini digunakan untuk mengukur modal tersedia untuk investasi dan pembayaran hutang yang ada. Rasio ini diperoleh dengan arus kas operasi dibagi 
dengan pengeluaran modal. Dalam hal ini,

Rasio yang tinggi menunjukkan kemampuan yang tinggi dari arus kas dalam membiayai pengeluaran modal.

4. Rasio Arus Kas Terhadap Laba Bersih

Rasio ini berguna untuk mengukur kemampuan perusahaan dalam memenuhi kewajiban kas di masa mendatang.

\section{Metode Penelitian}

Penelitian ini dilakukan pada PT Asuransi Ramayana Tbk, data keuangan diambil dari website bursa efek Indonesia yaitu www.idx.com. Jenis penelitian yang digunakan peneliti adalah metode kuantitatif deskriptif. Sumber data yang digunakan dalam penelitian ini adalah sumber data sekunder, yaitu data laporan keuangan tahunan yang telah dipublikasikan. Teknik pengumpulan data dokumentasi dan kepustakaan.

\section{Alat Analisis}

Menurut Darsono dan Ashari (2005:91) dalam Oktaviana (2017), alat analisis rasio arus kas yang diperlukan untuk menilai kinerja keuangan perusahaan antara lain:

1. Rasio Arus Kas operasi

2. Rasio Arus Kas Operasi terhadap Total Hutang

3. Rasio Arus Kas Operasi terhadap Pengeluaran Modal
4. Rasio Arus Kas Operasi terhadap Laba Bersih

\section{Hasil Penelitian}

Rasio Arus Kas Operasi

Tabel 4.4 Hasil Rasio Arus Kas Operasi

\begin{tabular}{cccc}
\hline Tahun & $\begin{array}{c}\text { Total Arus } \\
\text { Kas Operasi }\end{array}$ & $\begin{array}{c}\text { Kewajiban } \\
\text { Lancar }\end{array}$ & Presentase \\
\hline 2014 & $(3.294)$ & 166.961 & $-1.98 \%$ \\
2015 & 37.129 & 153.810 & $24.14 \%$ \\
2016 & 34.788 & 160.096 & $21.73 \%$ \\
2017 & 17.543 & 196.433 & $8.94 \%$ \\
\hline
\end{tabular}

Sumber: Data Olahan, 2019

Hasil analisis rasio Arus Kas Operasi pada tahun 2014 rasio arus kas sebesar 0.01973 yang berarti untuk setiap seratus rupiah kewajiban lancar dijamin dengan 1.98 rupiah arus kas operasi. Tahun 2015 rasio arus kas sebesar 0.24139 yang berarti untuk setiap seratus rupiah kewajiban lancar dijamin dengan 24.14 rupiah arus kas operasi. Tahun 2016 rasio arus kas sebesar 0.21729 yang berarti untuk setiap seratus rupiah kewajiban lancar dijamin dengan 21.73 rupiah arus kas operasi. Tahun 2017 rasio arus kas sebesar 0.8930 yang berarti untuk setiap seratus rupiah kewajiban lancar dijamin dengan 8.94 rupiah arus kas operasi.

Rasio Total Hutang

Tabel 4.5 Hasil Rasio Total Hutang

\begin{tabular}{cccc}
\hline Tahun & $\begin{array}{c}\text { Jumlah Arus } \\
\text { Kas Operasi }\end{array}$ & $\begin{array}{c}\text { Total } \\
\text { Hutang }\end{array}$ & Presentase \\
\hline 2014 & $(3.294)$ & 1.140 .273 & $-0.28 \%$ \\
2015 & 37.129 & 1.134 .651 & $3.28 \%$ \\
2016 & 34.788 & 1.115 .704 & $3.12 \%$ \\
2017 & 17.543 & 1.056 .423 & $1.67 \%$ \\
\hline
\end{tabular}

Sumber : Data Olahan, 2019 
Hasil analisis rasio Total Hutang pada tahun 2014 rasio total hutang menunjukan rasio sebesar 0.00288 . Artinya total hutang asuransi dijamin oleh arus kas operasi bersih tahun 2014 sebesar $0.28 \%$. Tahun 2015 rasio total hutang menunjukan rasio sebesar 0.03272. Artinya total hutang asuransi dijamin oleh arus kas bersih tahun 2015 sebesar $3.28 \%$. Tahun 2016 rasio total hutang menunjukan rasio sebesar 0.03118 . Artinya total hutang asuransi dijamin oleh arus kas bersih tahun 2016 sebesar 3.12\%. Tahun 2017 rasio total hutang menunjukan rasio sebesar 0.01660 . Artinya total hutang asuransi dijamin oleh arus kas bersih tahun 2017 sebesar $1.67 \%$.

Rasio Pengeluaran Modal

Tabel 4.6 Hasil Rasio Pengeluaran Modal

\begin{tabular}{cccc}
\hline Tahun & $\begin{array}{c}\text { Jumlah Arus } \\
\text { Kas Operasi }\end{array}$ & $\begin{array}{c}\text { Pengeluaran } \\
\text { Modal }\end{array}$ & Presentase \\
\hline 2014 & $(3.294)$ & 213.230 & -0.01 kali \\
2015 & 37.129 & 225.149 & 0.16 kali \\
2016 & 34.788 & 295.767 & 0.11 kali \\
2017 & 17.543 & 339.242 & 0.05 kali \\
\hline
\end{tabular}

Sumber : Data Olahan, 2019

Hasil analisis rasio Pengeluaran Modal pada tahun 2014 rasio pengeluaran modal sebesar -0.01 menunjukan bahwa kemampuan arus kas operasi dalam membiayai pengeluaran modal tahun 2014 sebesar -0.01 kali. Tahun 2015 rasio pengeluaran modal sebesar 0.16 menunjukan bahwa kemampuan arus kas operasi dalam membiayai pengeluaran modal tahun 2015 sebesar 0.16 kali. Tahun
2016 rasio pengeluaran modal sebesar 0.11 menunjukan bahwa kemampuan arus kas operasi dalam membiayai pengeluaran modal tahun 2016 sebesar 0.11 kali. Tahun 2017 rasio pengeluaran modal sebesar 0.5 menunjukan bahwa kemampuan arus kas operasi dalam membiayai pengeluaran modal tahun 2017 sebesar 0.05 kali.

Rasio Laba Bersih

Tabel 4.7 Hasil Rasio Laba Bersih

\begin{tabular}{cccc}
\hline Tahun & $\begin{array}{c}\text { Jumlah Arus } \\
\text { Kas Operasi }\end{array}$ & Laba Bersih & Presentase \\
\hline 2014 & $(3.294)$ & 54.069 & -0.06 kali \\
2015 & 37.129 & 60.156 & 0.61 kali \\
2016 & 34.788 & 67.875 & 0.51 kali \\
2017 & 17.543 & 58.006 & 0.30 kali \\
\hline
\end{tabular}

Sumber : Data Olahan, 2019

Hasil analisis rasio Laba Bersih. Pada tahun 2014 sebesar -0.06, tahun 2015 sebesar 0.61, tahun 2016 sebesar 0.51 dan pada tahun 2017 sebesar 0.30 .

\section{Pembahasan}

Rasio Arus Kas Operasi

Pada tahun 2014, dapat diartikan bahwa rasio arus kas operasi perusahaan belum baik karena bernilai negatif. Rasio arus kas operasi PT Asuransi Ramayana Tbk. Di tahun 2015 terjadi kenaikan. Rasio arus kas operasi di tahun 2016 terjadi penurunan. Dan rasio arus kas operasi di tahun 2017 kembali terjadi penurunan.

Dari data PT Asuransi Ramayana Tbk tahun 2014-2017 rasio cenderung mengalami fluktuasi dan rasio tertinggi 
terjadi pada tahun 2015 yaitu sebesar 0.24139. Namun walaupun terjadi peningkatan rasio pada tahun 2015, akan tetapi rasio yang dihasilkan dari tahun 2014-2017 tersebut kurang dari 1 (satu) sehingga kemungkinan besar perusahaan tidak mampu membayar kewajiban lancarnya melalui arus kas dari aktivitas operasi saja. Jika hal ini terjadi, maka akan berdampak buruk bagi kelancaran dan kelangsungan hidup perusahaan dalam membiayai pelaksanaan kegiatan operasi perusahaan. Untuk mengatasi rasio arus kas operasi yang rendah, PT Asuransi Ramayana Tbk dapat mempercepat periode penagihan piutang usaha dan menambah pendapatan arus kas masuk dari aktivitas operasi perusahaan.

\section{Rasio Total Hutang}

Pada tahun 2014, rasio total hutang PT Asuransi Ramayana Tbk. bernilai negatif. Rasio arus kas total hutang PT Asuransi Ramayana Tbk. Di tahun 2015 mengalami kenaikan. Rasio arus kas total hutang PT Asuransi Ramayana Tbk. Di tahun 2016 mengalami penurunan. Dan rasio arus kas total hutang PT Asuransi Ramayana Tbk. Di tahun 2017 mengalami kenaikan.

Dari hasil perhitungan rasio tersebut dapat dilihat bahwa kinerja keuangan PT Asuransi Ramayana Tbk memiliki kemampuan yang rendah dalam membayar total hutangnya melalui arus kas operasi bersih perusahaan yang dapat dilihat dari perhitungan rasio yang berada di bawah 1 $(<1)$, sehingga perusahaan harus memiliki sumber arus kas lain selain arus kas normal untuk menutupi total hutangnya. Jika perusahaan kekurangan dana likuid untuk membayar kewajiban-kewajibannya yang akan jatuh tempo bisa mengakibatkan kebangkrutan yang dapat merugikan semua pihak. Peningkatan rasio terjadi karena arus kas operasi tinggi sebanding dengan total hutang yang tinggi, sedangkan penurunan rasio terjadi karena arus kas operasi rendah dibandingkan total hutangnya.

\section{Rasio Pengeluaran Modal}

Rasio pengeluaran modal PT Asuransi Ramayana Tbk. untuk tahun 2014 adalah -0.01 berada dibawah $1 \quad(<1)$ atau kemampuan arus kas dalam membiayai pengeluaran modal perusahaan sebesar 0.01 kali. Hal ini berarti kinerja perusahaan tidak cukup memiliki kemampuan dalam menutupi biaya pengeluaran modal. Pada tahun 2015 adalah 0.16 berada dibawah 1 $(<1)$ tetapi mengalami kenaikan menjadi 0.16 kali, hal ini berarti adanya peningkatan kinerja perusahaan. Dan di tahun 2016 adalah 0.11 berada dibawah $1 \quad(<1)$ dan mengalami penurunan menjadi 0.11 kali, hal ini disebabkan adanya penurunan 
kinerja pada perusahaan. Dan pada tahun 2017 adalah 0.05 berada dibawah $1(<1)$ dan mengalami penurunan menjadi $0.05 \%$.

Dari hasil perhitungan rasio pengeluaran modal, kinerja keuangan PT Asuransi Ramayana Tbk tahun dari tahun 2014-2017 menunjukan rasio yang rendah kemungkinan perusahaan mengalami kesulitan dalam membiayai pengeluaran modal seperti membayar dividen kepada nasabah melalui arus kas operasi saja. Rasio berada dibahwa $1(<1)$ diakibatkan karena arus kas operasi lebih kecil dibandingkan pengeluaran modal.

\section{Rasio Laba Bersih}

PT Asuransi Ramayana Tbk dalam 4 tahun mendatang kemungkinan tidak dapat memenuhi kewajiban tidak mencukupi dan dapat dilihat bahwa nilai rasio berada dibawah $1 \quad(<1)$. Kondisi ini sangat berbahaya bagi perusahaan karena dapat mempengaruhi kepercayaan berbagai pihak lain yang menjalin kerjasama dengan PT Asuransi Ramayana Tbk, dan kemungkinan perusahaan belum mampu membayar dividen kepada nasabah dengan menggunakan arus kas operasi.

\section{Kesimpulan}

Berdasarkan dari hasil penelitian dan pembahasan pada penelitian ini, arus kas operasi perusahaan mengalami kondisi terburuk pada tahun 2014, karena jumlah arus kas bersih perusahaan tersebut bernilai negatif dibandingkan tahun-tahun selanjutnya. Hasil analisis rasio arus kas dalam menilai kinerja keuangan pada PT Asuransi Ramayana Tbk tidak baik mengingat rata-rata rasio yang dihasilkan rendah. Hasil analisis rasio arus kas selama tahun periode penelitian menunjukan kurang dari satu $(<1)$ tetapi perusahaan mampu menghasilkan laba atau keuntungan.

\section{Saran}

Berdasarkan pada hasil penelitian ini, penulis menyarankan agar perusahaan harus mengkaji ulang hal-hal apa saja yang menyebabkan penurunan arus kas aktivitas operasi bersih, serta melakukan analisa terhadap hutang-hutangnya. Perusahaan sebaiknya melakukan perbaikan pada sistem perputaran kas-nya untuk meningkatkan kinerja perusahaan. Biaya operasional perusahaan sebisa mungkin harus dioptimalkan dalam menghindari timbulnya kekurangan kas perusahaan untuk membayar kewajiban jangka pendeknya. Aktivitas investasi memang berdampak positif terhadap perusahaan di masa akan datang, akan tetapi pengeluaran untuk investasi yang berlebihan dapat menyebabkan kas perusahaan tidak likuid. 


\section{Daftar Pustaka}

Oktaviana, Analisis Laporan Arus Kas pada

Koperasi Lantang Tipo tahun 20142016, Yogyakarta. 2017

Fahmi, I. 2014. Bank \& Lembaga Keuangan dan lainnya Teori dan Aplikasi. Bandung: Alfabeta.

Fahmi, I. 2012. Analisis Kinerja Keuangan. Bandung: Alfabeta.

Kasmir. 2015. Pengantar Manajemen Keuangan. Jakarta: Kencana Prenada Media Group.

Kasmir. 2015. Analisis Laporan Keuangan. Jakarta: Raja Grafindo Persada

Soemarso. 2005. Akuntansi Suatu Pengantar. Edisi Revisi. Jakarta: PT Salemba.

Sofyan, Harahap. 2016. Analisis Kritis atas Laporan Keuangan. PT Raja Grafindo Persada. Jakarta.

Sofyan, 2011. Teori Akuntansi, Jakarta: PT, Raja Grafindo Persada. Jakarta

www.idx.com 